\title{
Study on the Application of Interesting Teaching Method in Professional Foreign Language Based on PDCA Cycle
}

\author{
Luming Wang \\ School of Environmental Engineering \\ Xuzhou University of Technology \\ Xuzhou, China \\ E-mail:714480071@qq.com
}

\section{Kai Qi}

School of Environmental Engineering

Xuzhou University of Technology

Xuzhou, China

E-mail:1459543071@qq.com

Jiaqiang Liu

School of Environmental Engineering

Xuzhou University of Technology

Xuzhou, China

E-mail:471435789@qq.com

Senyang $\mathrm{Hu}$

School of Environmental Engineering

Xuzhou University of Technology

Xuzhou, China

E-mail:676509527@qq.com

\author{
Ying Li \\ School of Environmental Engineering \\ Xuzhou University of Technology \\ Xuzhou, China \\ E-mail:1y131015@163.com
}

\author{
Xingcan Zheng \\ National Water Supply and Drainage Engineering \\ Technology and Research Center \\ Tianjin, China \\ E-mail:tjzxc@vip.sina.com \\ Qiang Liu \\ School of Environmental Engineering \\ Xuzhou University of Technology \\ Xuzhou, China \\ E-mail:498360210@qq.com
}

\begin{abstract}
Reasons for the lack of motivation of the students in the course of "professional foreign language" is investigated and analyzed by means of questionnaire investigation. A kind of interesting teaching method suits for Professional Foreign Language is proposed and practiced, aims to improve the effect of teaching. A comparative study of traditional teaching method and interesting teaching method is carried out in the course. The teaching effect is evaluated through examination and evaluation, and the students' satisfaction degree is investigated by network questionnaire. The result shows that the overall satisfaction of the students in the fun teaching group is up to 98 percent, which is higher than that in the traditional teaching group significantly. The total quality management model (Plan-Do-Check Action cycle, PDCA cycle) is applied to the course of teaching reform, aims to achieve the goal of continuous improvement.
\end{abstract}

Keywords: professional foreign language; interesting teaching; teaching reform; PDCA cycle

\section{INTRODUCTION}

With the development of modern science and technology and higher education, professional basic courses and professional courses are facing different problems and challenges, such as the class time is compressed while the teaching content is increasing. All these caused the burden of students generally increased. In this case, it is difficult to heighten the interest of study ${ }^{[1]}$.Qiu Guanwen and others ${ }^{[2]}$ supposed to define the aim of autonomous learning, to enhance the consciousness of autonomous learning, to conform and amend autonomous learning behaviors, finally to facilitate the systematical development. Students' activities and their ability, social relations, freedom and personality can be promoted.

Professional Foreign Language is an optional course for water supply and drainage science and engineering and environmental engineering in our university. The teaching method mainly focused on classroom teaching and self-study supplemented. Part of the contents makes full use of the network video resources to help students to know the current situation of water supply and drainage projects in the world and learn the advanced technology and concept of the countries. The purpose of the teaching is to cultivate students' ability of vocabulary, reading, translation and communication. However, the classroom performance and test results of previous students showed that students had 
poor verbal ability, unsatisfactory translation, insufficient studying motivation, which indicates that they fail to meet the training requirements of syllabus. The author thinks that setting up incentive mechanism, under the condition of fully understanding the reasons of students' lack of motivation, can make up for the deficiency when applying this teaching method.

Interesting teaching method, is defined as making teaching activities lively and interesting, turning the classroom into an alive stage, inspiring students' thinking, arousing their thirst for knowledge, and explaining the profound and incomprehensible scientific knowledge in a vivid and vigorous form, preventing or reducing senseless silence in class ${ }^{[4]}$. Fundamentally speaking, teaching is a kind of interaction, which can not be carried out without interactive teaching and learning. The teacher's feedback in the interaction timely can make the learner feel concerned by the teacher ${ }^{[5,6]}$.Liu Liwei $^{[7]}$ believed that emotional communication should be established common channel to harmonize relationship between teachers and students, and a pleasant atmosphere in the classroom should be created in order to meet the students' desire for success. He also viewed that flexible teaching methods should be adopted to mobilize students' enthusiasm. Jiang Junfeng [8] proposed a "combination of theory and practice interest teaching method" and acted it out. The results showed that it can effectively improve students' interest in learning, improve the learning effect of pattern recognition course. PDCA cycle (Plan-Do-Check-Action) is an effective management mode and has been used in various fields, having achieved remarkable results ${ }^{[9,10]}$.This teaching reform draws lessons from total quality management pattern in engineering project, taking the teaching quality enhancement as the project to carry on the management. The deepening and propelling of teaching reform in colleges, and the reform and innovation of inherent system, are embodied in the daily teaching management ${ }^{[11,12]}$, so as to satisfy the students and meet the aim of continuous improvement in teaching quality.

\section{IMPLEMENTATION OBJECT}

The students that in the class 1 and 2 of environmental engineering in our university were taken as the control group (88 people), and students of water supply and drainage science and engineering of grade 2014 were taken as the research group (110 people). Big class teaching was selected in both groups. There were no significant differences in gender composition, age composition, academic achievement or teachers between the two groups.

\section{RESEARCH METHODS}

\section{A. The Design of Interesting Teaching Methods}

Control group: Traditional teaching method is implemented.

Research group: Based on the research of early interactive teaching reform, students of class of water supply and drainage science and engineering and environmental engineering of Xuzhou Institute of Technology grade 2014 were selected as the research objects.

The motivation of the course was analyzed by questionnaire, 200 questionnaires investigation were distributed and 175 copies were collected. The effective recovery rate is $87.5 \%$. According to the results of investigation, the cause and effect diagram of lacking motivation for learning (showed in figure 1) and the number of points of insufficient learning power (showed in figure 2) are plotted to analyze the main causes of students' lack motivation of learning.

As shown in figure 2 , from $0 \%$ to $80 \%$ of the cumulative frequency is classified as category A problem, which is considered to be the main problem (single teaching method and single content) and should be focused on in management. The problem with a cumulative frequency in the range of 80 to 95 percent is classified as a category B problem, which is the secondary problem (too much memory knowledge and low learning goals and motivation levels) as the secondary important focus of management. The cumulative frequency in the $95 \%$ of $100 \%$ is classified as C problem, which is general problem (poor study style of and other reasons. According to the analysis of figure 1 and figure 2, the main problems come from the course and teachers, so we should take some measures in these two aspects to propel the motivation of the students.

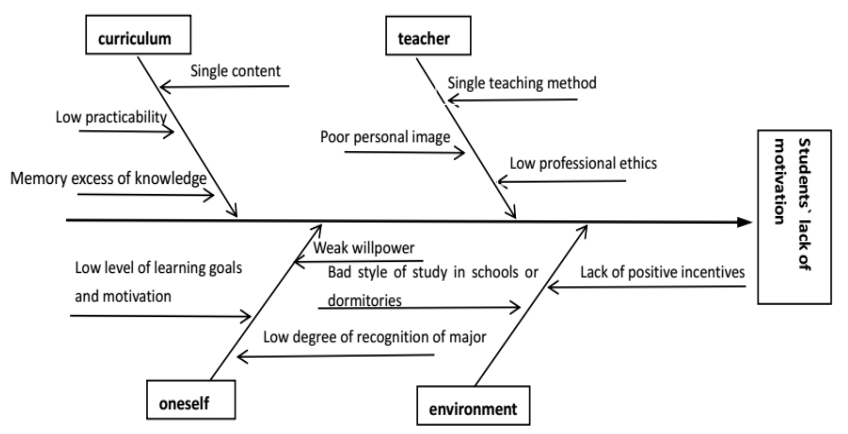

Figure 1 Analysis of lack of learning motivation

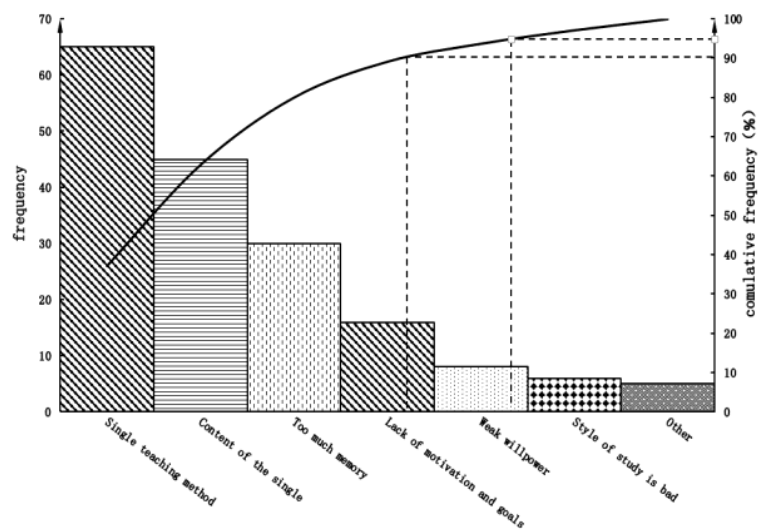

Figure 2 Point number arrangement diagram in lack of learning motivation 


\section{B. Implementation of Interesting Teaching Methods}

This teaching reform mainly took the form of I love remembering words competition between classes. The game was placed in specific courses, and supplemented by improving questioning methods to improve the effectiveness and interest of classroom questioning. APPs were also brought into the classroom to strengthen the learning function of mobile phone. All these measures were expected to enrich the teaching method, change the singularity of teaching content, and explore the interesting teaching method of Professional Foreign Language.

\section{1) I love remembering words competition}

The competition rules are similar to the ones referred to in reference 13 Discussion on interactive teaching mode of Professional Foreign Language for water and wastewater engineering.

\section{2) Method of class questioning methods improvement}

In the process of teaching, the teacher is the leading one and the student is the main part. If the teacher can take appropriate methods to set questions to guide students, to make full use of favorable factors, to cultivate students' interest actively, a relaxed and pleasant learning environment will be created. And the student may enjoy the pleasure in learning.

a) Taking the interest point as the cut-in point.

Hot spot and interest point from their daily life as cut-in point to proceed the course from shallow to deeper, then finally to the topic of the text gradually.

b) Ask questions from multi-angle.

Questions should be heuristic when they are set up we should make the, so that they can stimulate students' thinking and thirst for knowledge, and promote the development of students' divergent thinking.

\section{question}

c) Find interesting ways of choosing the object of the

In addition to improve the grades as a way to encourage students to answer questions, many optional respondents' choice ways were took to improve interest and active classroom atmosphere. For example, a small program was produced and students' ID numbers were input, and then a list can be drawn randomly like lottery. Or red envelopes were hand out through We Chat, and the luckiest one was going to answer the question. Or the object was selected by the former one. Students who can't answer the question can ask other students for help. Then both can gain the scores if he or she was correct.

\section{3) Bring APP to classroom}

Zhang Xiuping's research ${ }^{[15]}$ showed that $53.5 \%$ of students had to bring their cellphone to class, and $38.1 \%$ of them often carried cellphones in class, while only $1.2 \%$ of them never carried cellphones in class. At the same time, $97.7 \%$ of them use cellphones in class, and $31.7 \%$ of them use cellphones in every class. In addition, $22.9 \%$ of the students said that they spend more than 30 minutes in using their cellphones in class. Cellphones has entered into the daily life of college students. Just prohibiting cellphones in class is not realistic under this situation. The arrival of the era of media indicates the teaching method should be reformed and evolved, and the function of the mobile phone should be also enriched. We should guide students using the mobile phones properly and effectively in class.

Due to the peculiarity of the course Professional Foreign Language, students need to search the words, so it is necessary to recommend some online dictionary to them, such as the YouDao dictionary, Baidu Translate, Google translation and so on. Then teach them how to make full use of online dictionary consulting, classification and memorizing words. In addition, VOA (Voice of America) was recommended to them in the view of the weakness of their oral and listening. This APP updates daily articles in English and Chinese everyday. Students can not only hear the pure American pronunciation, accept all the latest news and information, do the corresponding exercises, they can also speak loudly with the reading, and share the spoken language to the comments section, compare with each other by the ranks and so on. After these methods to the reform of teaching process, not only the process of learning became more fun and competitive, but also the learning process extended beyond the classroom.

\section{Effect Test of the Teaching Methods}

Results of the students' final examination between the control group and the research group were compared and analyzed. At the end of the term, students' study habits and suggestions were traced in the form of online survey to test the teaching method by statistical analysis questionnaires.

\section{The Analysis of the Date}

Data were analysed by EXCEL and SPSS.

\section{RESULTS AND DISCUSSION}

\section{A. Comparison of Students' Theory final Exam Results}

The examination method is open-book, and the students should complete in 100 minutes. There were five types of the questions, which were filling the gaps, translating English into Chinese, translating Chinese into English, short-answer questions, and translating the abstract. The basic questions accounted for $60 \%$, the improving part was $30 \%$, and the comprehensive topic accounted for $10 \%$. From the point of the final exam paper grades, no significant difference between two groups of students' total points (shown in table 1). From the score point of each question, there was no obvious difference found between them (shown in table 2). However, difference appeared in improving questions (short-answer and translating abstract), scores in research group is higher than those in control group. The research group's answer much more meet the requirements of the writing of science and technology thesis more, and the terminology translation was more appropriate. From the examination process, the students in the research group handed out an average of 10 minutes earlier than the students 
in the control group, indicating that they are familiar with textbook knowledge and can find the answers quickly.

TABLE1.COMPARISON OF FINAL SCORES BETWEEN THE CONTROL GROUP AND THE RESEARCH GROUP

\begin{tabular}{|c|c|c|c|c|c|c|c|c|c|c|c|c|c|c|}
\hline \multirow{2}{*}{$\begin{array}{c}\text { Student } \\
\text { score } \\
\text { analysis }\end{array}$} & \multirow{2}{*}{ Number } & \multicolumn{2}{|c|}{$\begin{array}{l}\text { Excellence } \\
(90-100)\end{array}$} & \multicolumn{2}{|c|}{$\begin{array}{l}\text { Acceptable } \\
(80-89)\end{array}$} & \multicolumn{2}{|c|}{$\begin{array}{l}\text { Medium } \\
(70-79)\end{array}$} & \multicolumn{2}{|c|}{$\begin{array}{l}\text { Marginal } \\
(60-69)\end{array}$} & \multicolumn{2}{|c|}{$\begin{array}{l}\text { Poor } \\
(<60)\end{array}$} & \multirow{2}{*}{$\begin{array}{l}\text { The } \\
\text { highest }\end{array}$} & \multirow{2}{*}{$\begin{array}{l}\text { The } \\
\text { lowest }\end{array}$} & \multirow{2}{*}{$\begin{array}{l}\text { The } \\
\text { averag }\end{array}$} \\
\hline & & $\begin{array}{c}\text { Numb } \\
\text { er }\end{array}$ & $\begin{array}{l}\text { Propor } \\
\text { tion } \\
(\%)\end{array}$ & $\begin{array}{c}\text { Numb } \\
\text { er }\end{array}$ & $\begin{array}{c}\text { Propor } \\
\text { tion } \\
(\%)\end{array}$ & $\begin{array}{c}\text { Numb } \\
\text { er }\end{array}$ & $\begin{array}{c}\text { Propor } \\
\text { tion } \\
(\%)\end{array}$ & $\begin{array}{c}\text { Numb } \\
\text { er }\end{array}$ & $\begin{array}{c}\text { Propor } \\
\text { tion } \\
(\%)\end{array}$ & $\begin{array}{c}\text { Numb } \\
\text { er }\end{array}$ & $\begin{array}{l}\text { Propor } \\
\text { tion } \\
(\%)\end{array}$ & & & \\
\hline $\begin{array}{l}\text { Control } \\
\text { groupl }\end{array}$ & 43 & 10 & 23.26 & 18 & 41.86 & 6 & 13.95 & 7 & 16.28 & 2 & 4.65 & 95 & 45 & 81.3 \\
\hline $\begin{array}{l}\text { Control } \\
\text { group2 }\end{array}$ & 45 & 14 & 31.11 & 16 & 35.56 & 10 & 22.22 & 4 & 8.89 & 1 & 2.22 & 99 & 50 & 85.9 \\
\hline $\begin{array}{c}\text { Research } \\
\text { groupl }\end{array}$ & 39 & 11 & 28.21 & 20 & 51.28 & 6 & 15.38 & 1 & 2.56 & 1 & 2.56 & 99 & 56 & 84.4 \\
\hline $\begin{array}{c}\text { Research } \\
\text { group2 }\end{array}$ & 36 & 14 & 38.89 & 17 & 47.22 & 4 & 11.11 & 1 & 2.78 & 0 & 0.00 & 98 & 61 & 86.2 \\
\hline $\begin{array}{c}\text { Research } \\
\text { group3 }\end{array}$ & 35 & 6 & 17.14 & 15 & 42.86 & 9 & 25.71 & 4 & 11.43 & 1 & 2.86 & 96 & 47 & 78.4 \\
\hline
\end{tabular}

TABLE 2.THE CONTRAST BETWEEN CONTROL GROUP AND RESEARCH GROUP

\begin{tabular}{ccccccc}
\hline & $\begin{array}{c}\text { Numbe } \\
\mathrm{r}\end{array}$ & $\begin{array}{c}\text { 1. Correct rate } \\
(\%)\end{array}$ & $\begin{array}{c}\text { 1. Correct rate } \\
(\%)\end{array}$ & $\begin{array}{c}\text { 1. Correct rate } \\
(\%)\end{array}$ & $\begin{array}{c}\text { 1. Correct rate } \\
(\%)\end{array}$ & $\begin{array}{c}\text { 1. Correct rate } \\
(\%)\end{array}$ \\
\hline $\begin{array}{c}\text { Control } \\
\text { group1 }\end{array}$ & 43 & 70.78 & 83.93 & 77.79 & 72.22 & 47.27 \\
$\begin{array}{c}\text { Control } \\
\text { group2 }\end{array}$ & 45 & 61.82 & 83.64 & 80.09 & 67.27 & 53.70 \\
$\begin{array}{c}\text { Research } \\
\text { group1 }\end{array}$ & 39 & 65.45 & 81.82 & 70.91 & 83.64 & 66.67 \\
$\begin{array}{c}\text { Research } \\
\text { group2 }\end{array}$ & 36 & 70.56 & 83.46 & 90.14 & 85.80 & 65.39 \\
$\begin{array}{c}\text { Research } \\
\text { group3 }\end{array}$ & 35 & 60.12 & 79.00 & 87.22 & 88.06 & 59.72 \\
\hline
\end{tabular}

\section{B. The Results of The Internet Questionnaire Survey}

According to the network questionnaire survey that includes class satisfaction and subsequent learning status, the competitive teaching form inspired the students' learning enthusiasm and interest in the course effectively. In the process of the game, students' ability of coordination and organization was indirectly exercised, and the solidarity in class also promoted. Various ways of questioning not only activate the classroom atmosphere, shorten the distance between teachers and students, but also increase the interaction in different classes. The promotion of APP made classroom and class learning more interesting and diverse, extended the learning time, broadened the scope of the study to various fields diffusely, and increased interaction with other English lovers on the dimension. The satisfaction of traditional teaching method in control group was only $65 \%$, while $98 \%$ in research group. $95 \%$ students in research group said they hope the teacher continue to implement the interest teaching method.

\section{V.CONCLUSION}

Generally speaking, this activity achieved the purpose of teaching reform in advance basically. The interaction between teacher and students are more frequent and the students' learning interests were also inspired at the same time. Learning process was prolonged and this teaching method reform eventually played a guaranteed purpose of continuous learning and improved the effect of learning.

Teaching reform is not a quick success, but continuous improvement. It should be carried out to implement the comprehensive quality management implementation program (PDCA cycle), so that the teaching quality will be increased circularly. In the future, all the above methods will be implemented in Professional Foreign Language course. There are three proposals to strengthen the teaching effect.

a) Teaching in small classes if possible, which can make good management in the classroom and more frequent interaction.

b) Arrange students reading related books, papers, and articles etc after-school and making PPT in groups and report it in the classroom in some content. It can enrich student's thought and exercise the team cooperation ability through the process.

c) Set up a teaching team so that they can explain the text deeply and expand relevant according to their respective specialties to frontier knowledge.

The teaching quality improvement of professional course is facing many new situations and new problems. The improvement of teaching method should not only combine the need of the students and the characteristics of the course, but also ensure the action of PDCA cycle management so that the work of teaching management tend to be more standardized, scientific and normalized to promote the continuous improvement of teaching quality.

\section{ACKNOWLEDGMENTS}

This work was supported by the faculty research fund of Jiangsu Ministry of Housing and Urban and Rural Construction Project (NO.00730091). The authors also thank the support of Jiangsu Natural Science Foundation (NO. BK20151161), major projects of Natural Science Research in Jiangsu higher education institutions (NO.17KJA610004) and Xuzhou Science and Technology Project (NO. KC16SQ192).

\section{REFERENCES}

[1] Wu Shuang, Chen Ping, “On Stimulation of Students'Interest in Learning for Construction of Their Self-Taught System---With the Interesting Teaching of College Organic Chemistry as an Example",in the journal of southwest china normal university (Nature Science Edition), vol1,pp102-103,2017.

[2] Qiu Guanwen, Li Fusheng, Zhang Huijin,"College Autonomous Learning Development Mechanism“, in Journal of Anshun University,vol17,pp55-56,2015.

[3] Mou Wenqian, "The Logical Connotation of the Men's All-round Development", in Chongqing Social Science,vol4,pp41-46, 2010.

[4] Song Mingjing,'Research on the countermeasures of students' silence in classroom"., in Teaching and education,vol6,pp10-11, 2017.

[5] Hoseung Paul Byu, Karen Hallett, Christopher Essex Supporting Instructors in the creation of Online Distance Education Cource:Lessons Learned. EDUCATIONAL TECHNOLOGY, September-October 2000. 
[6] David Jonathan, Zheng Tai-nian, Ren Youqun, "Theoretical basis of learning environment", Shanghai: East China Normal University press, 2002 .

[7] Liu Liwei, "Talk about interesting teaching in English. In Education for Chinese After-school (theory),vol6 ,pp276-277,2016.

[8] Jiang Junfeng, "Based on the theory and practical interest teaching method, the teaching research of undergraduate course", in the journal of Higher education ,vol17,pp66-68,2015.

[9] Liu Jing. "The Application of PDCA Circulation in the Construction of Effective Classroom in Vocational Colleges", in Journal of Lanzhou Petrochemical polytechnic, vol14,pp66-68,2014.

[10] Li Ying, "Application of PDCA cycle in university teaching management", in Journal of Liaoning University of Technology (Social Science Edition),vol16,pp130-132,2014.

[11] Duan Jiali, Zou Hua,"Application of PDCA cycle in university teaching management". In China training, 2017.

[12] Yao Hongyan, Zhang Xiaoyang, "Application of improved PDCA cycle method in teaching management of medical independent colleges “, in China Higher Medicine Education,vol11,pp47-48,2016.

[13] Li Ying,Du Hongmei, "Discussion on interactive teaching mode of Professional Foreign Language for water and wastewater engineering", in China Electric Power Education, 127-128,2013.

[14] Tang Lihua, "Exploration on interesting teaching under the new curriculum", in Gansu Science and Technology,vol30,pp70-71,2014.

[15] Zhang Xiuping, "Investigation and analysis of the current situation of college students' mobile phone use", in Chinese Adult Education,vol21,pp66-69,2016. 